\title{
In Vitro Propagation and Recovery of Eight Apple and Two Pear Cultivars Held in a Germplasm Bank
}

\author{
Analí Lizárraga1, Marga Fraga², Javier Ascasíbar³, María Luz González ${ }^{1}$ \\ ${ }^{1}$ Department of Plant Physiology, University of Santiago de Compostela, Santiago de Compostela, Spain \\ ${ }^{2}$ Cultigar, Brión, Spain \\ ${ }^{3}$ Centro de Investigaciones Agrarias de Mabegondo INGACAL-CIAM, Abegondo, Spain \\ Email: mluz.gonzalez@usc.es
}

How to cite this paper: Lizárraga, A., Fraga, M., Ascasíbar, J. and González, M.L. (2017) In Vitro Propagation and Recovery of Eight Apple and Two Pear Cultivars Held in a Germplasm Bank. American Journal of Plant Sciences, 8, 2238-2254. https://doi.org/10.4236/ajps.2017.89150

Received: July 24, 2017

Accepted: August 15, 2017

Published: August 18, 2017

Copyright (c) 2017 by authors and Scientific Research Publishing Inc. This work is licensed under the Creative Commons Attribution International License (CC BY 4.0).

http://creativecommons.org/licenses/by/4.0/

\begin{abstract}
Eight apple (Malus $x$ domestica) and two pear (Pyrus communis) traditional cultivars of commercial interest were selected from the germplasm bank CIAM (Centro de Investigaciones Agrarias de Mabegondo, NW of Spain) one of the most important collections of The Iberian Peninsula. In order to define the establishment protocol, apical buds 1.0 - 1.5 millimetre length of the selected cultivars were established in solid mineral medium Murashige and Skoog (MS) with modified vitamins (thiamine 10X) and supplemented with 1 $\mathrm{mg} \cdot \mathrm{L}^{-1}$ 6-benzyladenine (BA), $0.2 \mathrm{mg} \cdot \mathrm{L}^{-1}$ gibberellic acid $\left(\mathrm{GA}_{3}\right)$ and $0.3 \mathrm{mg} \cdot \mathrm{L}^{-1}$ of indole-3-butyric acid (IBA). The highest shoot initiation rates were achieved with apple cultivar "Principe Grande" (55\%) and "Barburiña" pear cultivar (50\%); the lowest rate was obtained with apple cultivar "Camoesa" (11\%). Initiation rates for shoots culture varied between $22 \%$ and $37 \%$ for the other cultivars. The cytokinins BA, zeatin, 2-isopentyladenine (2iP) and thidiazuron (TDZ) were tested at concentrations of $0,0.25,0.5$ and $1 \mathrm{mg} \cdot \mathrm{L}^{-1}$ in the absence or presence of IBA $\left(0.1 \mathrm{mg} \cdot \mathrm{L}^{-1}\right)$ for the multiplication step. For all cultivars, the highest multiplication rates were obtained with medium supplemented with TDZ and also in media containing BA. The in vitro rooting success of shoots in medium with $0.1 \mathrm{mg} \cdot \mathrm{L}^{-1} \mathrm{IBA}$ without cytokinins, and the survival rate of plantlets acclimatized under greenhouse conditions depended on the genotype of the different cultivars. In vitro propagation of these ten traditional apple and pear cultivars in NW Spain has not previously been reported.
\end{abstract}

\section{Keywords}

Apple Shoots, Pear Shoots, Axillary Bud, Multiplication, Cytokinin, Gene Bank 


\section{Introduction}

Apple (Malus $x$ domestica) and pear (Pyrus communis) trees, both of which belong to the Rosaceae family, are very popular fruits in high demand because of their sweet taste and nutritional value. They are included among the best known and most highly consumed and economically important fruit trees in the world, along with citrus, Prunus fruits and table grapes. According to data published by FAO in 2013, an amount of 103,442,237 T of apples and pears were produced worldwide, making them two of the most widely produced fruits in the world [1]. Most of the traditional cultivars of fruit trees, which are held in germplasm banks, are of increasing interest both in Spain and worldwide. The conservation of these cultivars over centuries has remarkable advantages as the trees are highly adapted to the environmental conditions of the sites and their fruits have particular organoleptic characteristics; they also represent a potential genetic reserve for future improvement plans, as well as being an irreplaceable cultural heritage resource. Germplasm banks play an important role in the conservation of fruit trees [2]. In Galicia (NW Spain), the Mabegondo Agricultural Research Center CIAM-INGACAL germplasm bank contains one of the largest numbers of genetically characterized apple [3] and pear trees, and is one of the few germplasm banks in Spain dedicated to conserving traditional fruit in field collections [4]. However, the phytosanitary status of these trees in the field, due to the traditional propagation system, is disturbed and many of them are infected by viruses, endophytic bacterias and mycoplasmas. Following the guidelines of the European and Plant Protection Organization [5], which forms part of the World Trade Organization, fruit trees must be free of the most harmful viruses before the fruits can be marketed. The diseases must be eradicated and the material must be cleaned for long-term preservation in germplasm banks [6]. As it is well-known, in vitro culture of apical meristems [7] together with heat therapy are valuable tools for the recovery and eradication of the main viruses present in almost all apple and pear cultivars [8]. To carry this out, first of all it is essential the establishment of in vitro culture for micropropagation [9], and secondly virus removal [10] and recovery of different cultivars.

Specific protocols are required for establishment, multiplication and rooting [11] [12] of the different fruit cultivars in order to be able to sanitize them. In vitro micropropagation has been reported in several cultivars of apple [13] and pear trees propagated in vitro [14] [15] [16] [17]. Therefore, effective in vitro regeneration is a necessary precondition for the implementation of different biotechnological approaches in plant breeding.

Numerous studies have reported regeneration from apple and pear somatic tissues by organogenesis [18] [19] [20]. Plant regeneration has been shown to be influenced by several factors [21] [22], genotype, size, type, and age of explant, in vitro conditions (dark period, light intensity, and quality) and other factors such as orientation of leaf explants [23]. However, one of the most important factors before and during the regeneration process is the type and concentration of cy- 
tokinin applied. Thidiazuron and benzyladenine are the cytokinins most frequently used in regeneration systems for apple and pear trees [24] [25] [26] [27] [28], but their efficiency depends on genotype and other factors [22]. Other cytokinins such as zeatin, $2 \mathrm{iP}$ and kinetin have also been tested in several studies and have generally been found to be less active [28]. The development of axillary buds as a multiplication method has been used in some fruit cultivars [29] as is one of the most effective methods of maintaining the genetic stability of cultivars. The rooting and acclimatization success depends on the genotype of each cultivar, the different growth regulators used and external factors [11].

The aim of this study has been the in vitro establishment of the different selected apple and pear trees cultivars for their multiplication and rooting in order to know their hormonal requirements for micropropagation and to acquire enough material for further investigation related with virus eradication.

\section{Materials and Methods}

\subsection{Plant Material}

Plant material of eight Galician traditional apple cultivars "Cacharela", "Camoesa", "Repinaldo", “Tres en Cunca", "Gravillán", "Ollo Mouro", "José Antonio" and "Príncipe Grande", and two pear cultivars "Barburiña" and "Manteca Oscura" were obtained from apical buds of genetically characterized dormant cuttings. Plant material belonging to the CIAM Germplasm Bank was collected in January 2012, 2013 and 2014.

\subsection{Initiation of Aseptic Cultures, Media and Culture Conditions}

Dormant cuttings were washed thoroughly under running tap water for twenty minutes and surface sterilized with $8 \%(\mathrm{w} / \mathrm{v})$ Capluq-50 fungicide solution, before being dried and wrapped in plastic film. The cuttings were then stored at $4^{\circ} \mathrm{C}$ for one month. The cuttings were sprouted in a phytotron, at $25^{\circ} \mathrm{C}$ day and $18^{\circ} \mathrm{C}$ night under a photoperiod of 16 hours. The new shoots of length more than $2 \mathrm{~cm}$ were excised and the basal end was sealed with paraffin wax. Then were sterilized with $10 \%$ sodium hypochlorite solution plus one drop of Tween $20^{\circ}$ for 15 minutes and were washed three times with sterile distilled water in order to remove traces of chlorine before establishment on the in vitro culture. All shoot tips $(1.0-1.5 \mathrm{~mm})$ were isolated and cultured for four weeks on basal MS medium with mineral salts [30], modified MS vitamins and 3\% (w/v) sucrose, and solidified with $7 \%$ microagar (Duchefa) containing $1 \mathrm{mg} \cdot \mathrm{L}^{-1} \mathrm{BA} ; 0.2$ $\mathrm{mg} \cdot \mathrm{L}^{-1} \mathrm{GA}_{3}$ and $0.3 \mathrm{mg} \cdot \mathrm{L}^{-1} \mathrm{IBA}$ [31]. The $\mathrm{pH}$ of the medium was adjusted to 5.8 with $1 \mathrm{~N} \mathrm{NaOH}$ before autoclaving at $121^{\circ} \mathrm{C}$ for 20 minutes. The medium was dispensed $(25 \mathrm{~mL})$ in $90 \mathrm{~mm}$ diameter sterile Petri dishes (Sterilin ${ }^{\circledR}$ ) and was covered with sterile filter paper to prevent growth of endophytic bacteria. All cultures were transferred to a growth chamber at $25^{\circ} \mathrm{C} \pm 1^{\circ} \mathrm{C}$ day and $18^{\circ} \mathrm{C} \pm$ $1^{\circ} \mathrm{C}$ night with a light intensity of $40 \mu \mathrm{mol} \cdot \mathrm{m}^{-2} \cdot \mathrm{s}^{-1}$ illuminated by white fluorescent lamps $\left(50 \mathrm{~W}^{\mathrm{O}} \mathrm{sram}{ }^{\oplus}\right)$ and a $16 \mathrm{~h}$ photoperiod. 


\subsection{Shoot Multiplication and Rooting}

The explants were cultured for four weeks before being transferred to tubes (22 $\times 150 \mathrm{~mm}$ ) containing $20 \mathrm{~mL}$ of MS basal medium of the same composition as before but without gibberellic acid $\left(\mathrm{GA}_{3}\right)$. After two subcultures in tubes, the explants were transferred to $350 \mathrm{~mL}$ jars $(\mathrm{n}=9)$ for shoot multiplication, containing each jar six explants (total $n=54$ ) of a minimum length of $10-15 \mathrm{~mm}$ with 3 - 5 leaves per bud, in $50 \mathrm{~mL}$ of MS medium supplemented with different concentrations $\left(0,0.25,0.5\right.$ and $\left.1 \mathrm{mg} \cdot \mathrm{L}^{-1}\right)$ of four cytokinins (BA, Zea, 2iP or TDZ), with or without auxin IBA $\left(0.1 \mathrm{mg} \cdot \mathrm{L}^{-1}\right)$. Shoot explants were subcultured onto fresh medium of the same composition every 4 weeks. After sixth subculture in jars, healthy elongated apple and pear shoots of a minimum length of $15-20$ $\mathrm{mm}$ and with at least two expanded leaves were selected for rooting. These shoots were excised from the explants and transferred to rooting medium consisting of MS basal medium supplemented with $0.1 \mathrm{mg} \cdot \mathrm{L}^{-1}$ of IBA, $30 \mathrm{~g} \cdot \mathrm{L}^{-1}$ of sucrose, and $7 \mathrm{~g} \cdot \mathrm{L}^{-1}$ agar, or on MS 0 basal medium, without growth regulators, for 28 days.

\subsection{Transplantation and Acclimatization of Plantlets}

After 4 weeks culture in rooting medium, the rooted shoots were washed in water to remove agar debris and placed in 40-well trays containing a mixture of $60 \%$ blonde peat substrate, $20 \%$ crust, $10 \%$ coconut fiber and $10 \%$ black peat. Each tray was placed in polystyrene boxes and covered with transparent plastic film to maintain high relative humidity and to allow entry of light. The trays were placed in a rooting chamber at a fixed temperature of $24^{\circ} \mathrm{C} \pm 2{ }^{\circ} \mathrm{C}$ with photoperiod of 16 light hours. After one month, the plantlets were transferred to greenhouse conditions, in a tunnel with a water spray fog irrigation system, mesh shading and warm bed to protect the shoots from low temperatures. The plantlets were held for one week under these conditions before the film was removed from each tray and the tunnel cover was opened slowly. Finally, the surviving rooted plantlets were transferred to individual pots containing substrate of the same composition and placed in a greenhouse, with shading mesh, controlled misting and environmental photoperiod. Percentage survival data were determined 4 weeks after transplanting the plantlets.

\subsection{Statistical Analysis}

The shoot multiplication developed with cytokinins (BA, Zea, 2iP and TDZ) at different concentrations $\left(0.25,0.5\right.$ and $\left.1 \mathrm{mg} \cdot \mathrm{L}^{-1}\right)$ with and without IBA $(0.1$ $\mathrm{mg} \cdot \mathrm{L}^{-1}$ ), plus control in (MS 0 ) for each apple and pear tree cultivar data resulted in a total of 24 treatments in each cultivar $(n=54)$. These data were analyzed using the statistical package SPSS version 20.0 [32]. Analysis of variance (ANOVA) was performed $(\mathrm{P}<0.05)$. Finally, Tukey's HSD post-hoc test $(\mathrm{P}<0.05)$ was applied for comparison of means. 


\section{Results}

\subsection{Initiation of Aseptic Cultures and Establishment}

The number of apical buds from axillary shoots available in each of the cultivars was variable due to the different size of the cuttings collected in the field. On the other hand, contamination by endophytic organisms, mainly bacteria, greatly affected the development of apex cultures. The use of sterile filter paper covering the plates, slows down the growth of endophytic bacteria, helping the explants development. However, endophytic bacterias proliferate faster on plates without filter paper. The phytosanitary status was therefore a determining factor for the success of the establishment and propagation of each cultivar affecting their development, and presence of bacterial colonies in the medium just where the basal end of shoot cultured was observed. Mineral MS medium supplemented with $1 \mathrm{mg} \cdot \mathrm{L}^{-1} \mathrm{BA}, 0.2 \mathrm{mg} \cdot \mathrm{L}^{-1} \mathrm{GA}_{3}$ and $0.3 \mathrm{mg} \cdot \mathrm{L}^{-1} \mathrm{IBA}$ was used for establishment in aseptic culture. The highest survival rate at establishment was obtained with the apple cultivar "Príncipe Grande" (55\%), followed by the apple cultivar "José Antonio" and the pear cultivar "Barburiña" (both with a survival rate of 50\%) (Table 1). The survival rates of the remaining apple and pear cultivars were between 22 and 37\%. The lower survival rate was in the apple cultivar "Camoesa" with only $11 \%$.

\subsection{Shoot Multiplication}

For all cultivars, the effects of different concentrations of cytokinins on in vitro axillary shoot development are presented in the following figures (Figures 1-4).

The best response to micropropagation of the eight apple and two pear cultivars was always obtained in the presence high concentrations $\left(0.5\right.$ and $\left.1.0 \mathrm{mg} \cdot \mathrm{L}^{-1}\right)$ of a cytokinin (TDZ or BA) in the medium. However, treatments for multiplication of axillary shoots with all different concentrations of zeatin and $2 \mathrm{iP}$, with or

Table 1. Establishment in vitro culture of eight apples and two pears cultivars. The cultivars marked with ${ }^{\star}$ belong to pear trees.

\begin{tabular}{llcc}
\hline Cultivars & Year & $\mathrm{N}^{\circ}$ of buds established in vitro & Survival in vitro (\%) \\
"Repinaldo" & 2012 & 11 & 27.27 \\
“Tres en Cunca" & 2012 & 09 & 22.22 \\
"Cacharela" & 2013 & 07 & 28.57 \\
"Camoesa" & 2013 & 27 & 11.11 \\
"Gravillán" & 2013 & 28 & 25.00 \\
"Ollo Mouro" & 2013 & 10 & 30.00 \\
"Barburiña” & 2013 & 06 & 50.00 \\
"José Antonio" & 2014 & 08 & 50.00 \\
"Príncipe Grande" & 2014 & 09 & 55.55 \\
"Manteca Oscura"* & 2014 & 08 & 37.50 \\
\hline
\end{tabular}




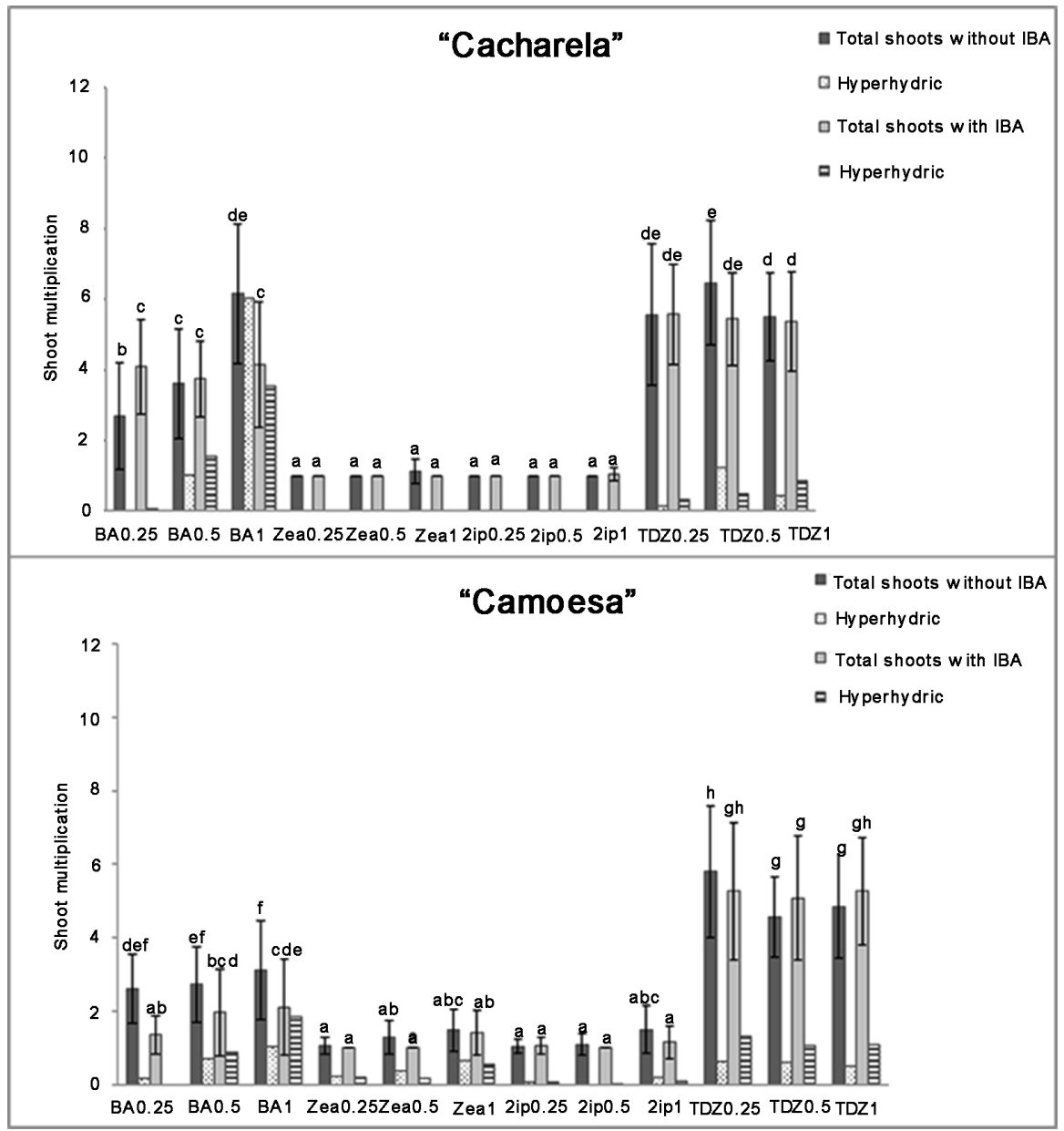

Figure 1. Effects of BA, Zea, 2iP and TDZ at three concentrations $\left(0.25,0.5\right.$ and $\left.1 \mathrm{mg} \cdot \mathrm{L}^{-1}\right)$ with and without IBA $\left(0.1 \mathrm{mg} \cdot \mathrm{L}^{-1}\right)$ on shoot multiplication after 4 weeks. Bars represent the standard deviation (SD). Means denoted by different letters are significantly different (Tukey $\mathrm{P}=0.05$ ).

without IBA, yielded very low multiplication rates in all cultivars. The optimum concentration of cytokinin for shoot development varied depending on the cultivar. Although TDZ yielded the highest mean rates of shoot formation, at the highest concentrations $\left(1.0 \mathrm{mg} \cdot \mathrm{L}^{-1}\right)$ many shoots from different cultivars were hyperhydric showing symptoms like thick stems and leaves, with anomalous leaf morphology and very short stems that made posterior subculture and rooting difficult (Figure 5).

\subsection{Rooting and Plantlet Acclimatization}

Emergence of the root primordia at the basal part of the shoots was observed after two weeks. The percentage of rooted shoots, the number of roots developed per rooted shoot, and the length of the longest root were recorded after culture of the explants for four weeks under the established light and temperature conditions. The cultivars "Camoesa" and "Repinaldo" yielded the highest rooting rates (both $91 \%$ ) in MS medium containing IBA $\left(0.1 \mathrm{mg} \cdot \mathrm{L}^{-1}\right)$, with a maximum 


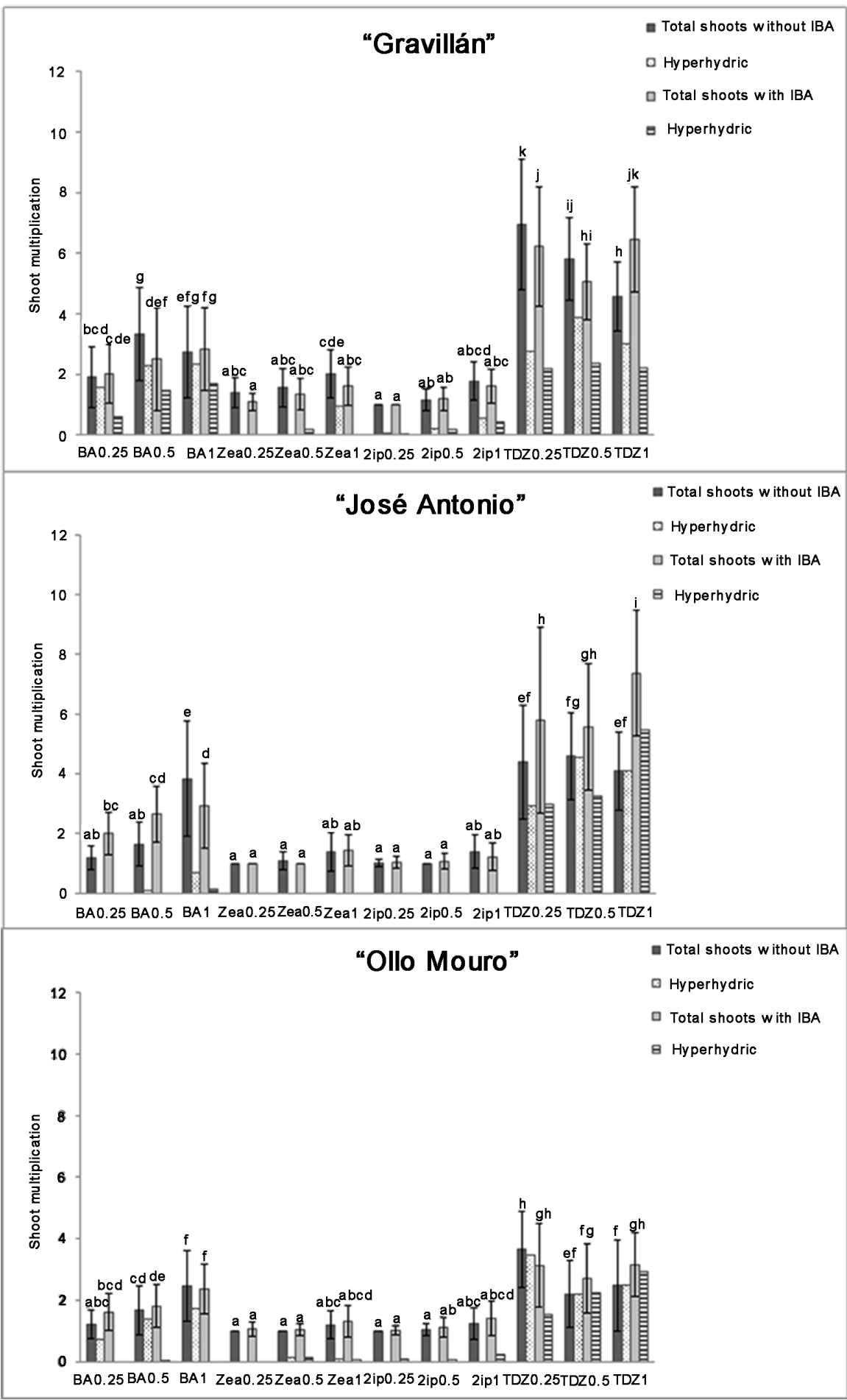

Figure 2. Effects of BA, Zea, $2 \mathrm{iP}$ and TDZ at three concentrations $\left(0.25,0.5\right.$ and $\left.1 \mathrm{mg} \cdot \mathrm{L}^{-1}\right)$ with and without IBA $\left(0.1 \mathrm{mg} \cdot \mathrm{L}^{-1}\right)$ on shoot multiplication after 4 weeks. Bars represent the standard deviation (SD). Means denoted by different letters are significantly different (Tukey $\mathrm{P}=0.05$ ).

mean number of 5.67 roots per shoot in the cultivar "Camoesa" and of 4.12 roots in the cultivar "Repinaldo" (Table 2), but lower rooting rates and number of roots were obtained when the shoots of both of these cultivars were transferred 


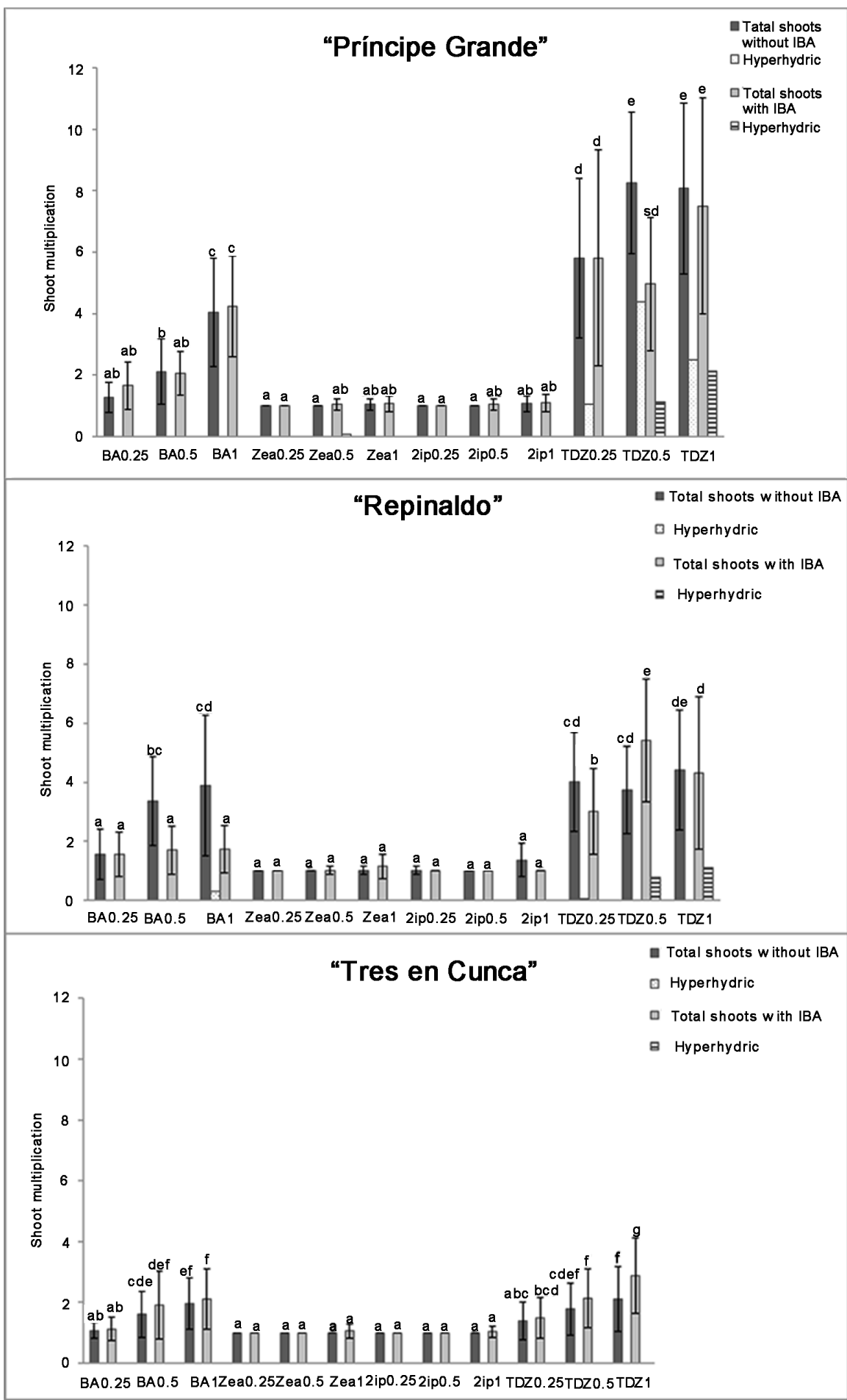

Figure 3. Effects of BA, Zea, $2 \mathrm{iP}$ and TDZ at three concentrations $\left(0.25,0.5\right.$ and $\left.1 \mathrm{mg} \cdot \mathrm{L}^{-1}\right)$ with and without IBA $\left(0.1 \mathrm{mg} \cdot \mathrm{L}^{-1}\right)$ on shoot multiplication after 4 weeks. Bars represent the standard deviation (SD). Means denoted by different letters are significantly different (Tukey $\mathrm{P}=0.05$ ).

to MS0 medium without auxin (Table 2). Some shoots only rooted in medium containing auxin ("Cacharela" and "Príncipe Grande"), while other cultivars only rooted successfully in the basal medium MS0 ("Ollo Mouro" and pear 


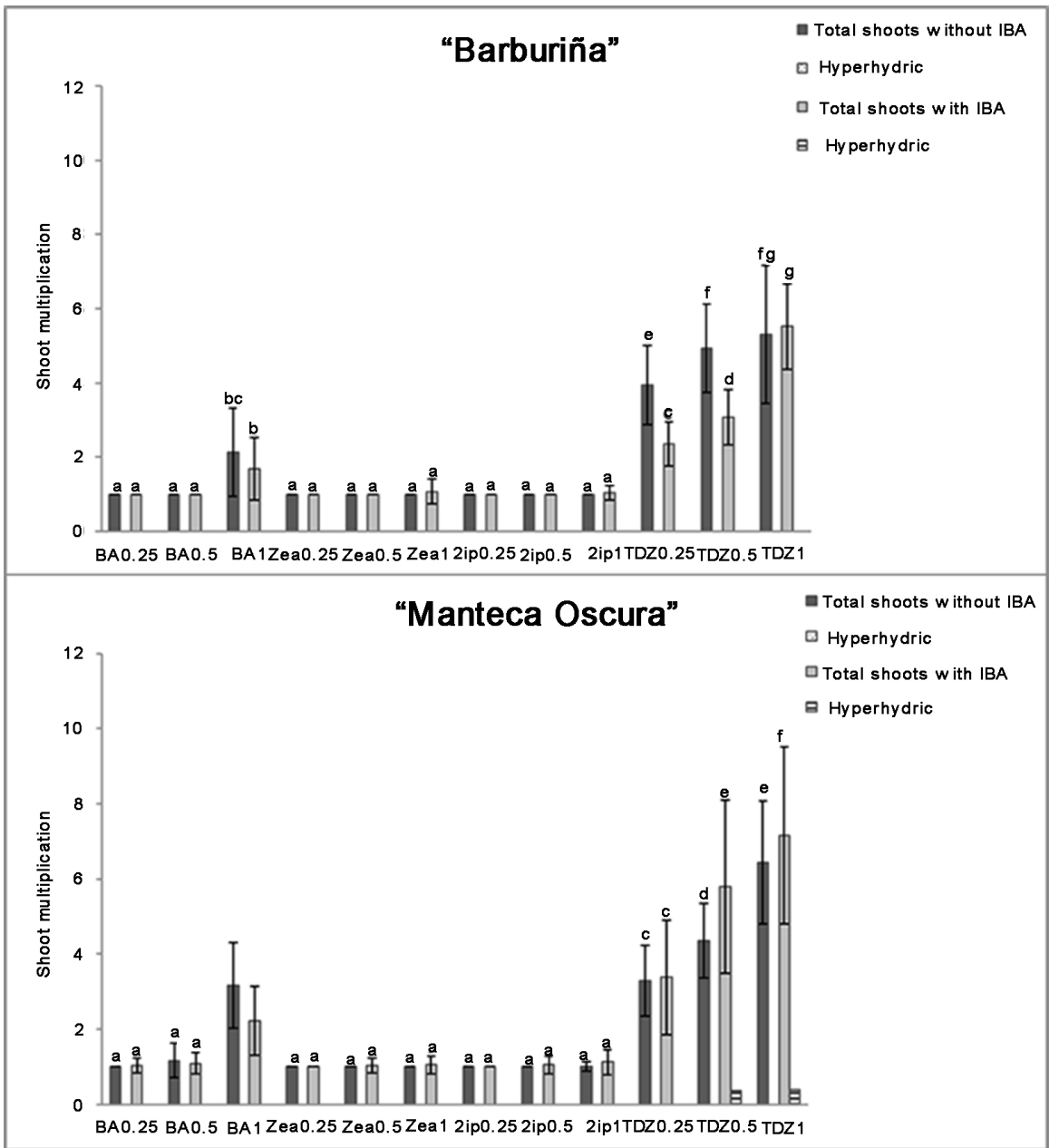

Figure 4. Effects of BA, Zea, $2 \mathrm{iP}$ and TDZ at three concentrations $\left(0.25,0.5\right.$ and $\left.1 \mathrm{mg} \cdot \mathrm{L}^{-1}\right)$ with and without IBA $\left(0.1 \mathrm{mg} \cdot \mathrm{L}^{-1}\right)$ on shoot multiplication after 4 weeks. Bars represent the standard deviation (SD). Means denoted by different letters are significantly different (Tukey $\mathrm{P}=0.05$ ).

"Manteca Oscura"). The apple cultivar "Tres en Cunca" did not root under any of the conditions studied. The survival rates of the plantlets acclimatized for four weeks were very variable (Table 2) being $100 \%$ in "Principe Grande" and values between $50 \%$ and $96.8 \%$ for the other cultivars of both apple and pear trees. The complete procedure for micropropagation is illustrated in Figure 6.

\section{Discussion}

A micropropagation protocol was developed from apices of apple and pear shoots cultured in vitro. The effects of several cytokinins and AIB auxin on micropropagation were examined.

The common establishment medium for all apple and pear cultivars consisted of solid MS mineral supplemented with BA $\left(1 \mathrm{mg} \cdot \mathrm{L}^{-1}\right), \mathrm{GA}_{3}\left(0.2 \mathrm{mg} \cdot \mathrm{L}^{-1}\right)$ and IBA $\left(0.3 \mathrm{mg} \cdot \mathrm{L}^{-1}\right)$ [31]. The combined effect of $\mathrm{BA}$ and $\mathrm{GA}_{3}$ for establishment of the in vitro culture of fruit trees has previously been reported for pear trees [14] and apple trees [21], even when starting from buds and apple tree nodes [33]. 

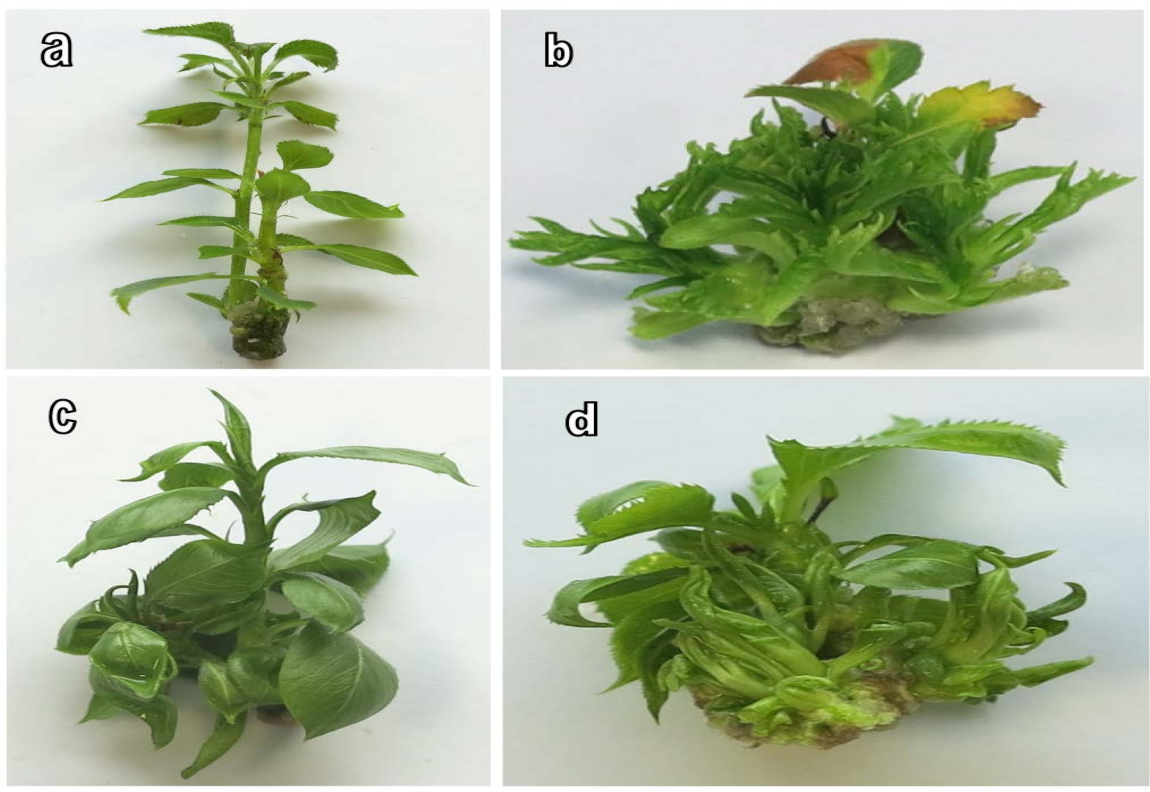

Figure 5. Normal development of apple (a) and pear shoots (c) in media containing BA, and hyperhydric shoots obtained with a high concentration $\left(1 \mathrm{mg} \cdot \mathrm{L}^{-1}\right)$ of the cytokinin TDZ in apple and pear shoots (b), (d) respectively.

Table 2. Effect of IBA on in vitro rooting and acclimatization of shoots of apple and pear cultivars, after 4 weeks in ex vitro conditions.

\begin{tabular}{|c|c|c|c|c|c|}
\hline Cultivars & $\begin{array}{c}\text { Concentration } \\
\text { IBA }\left(\mathrm{mg} \cdot \mathrm{L}^{-1}\right)\end{array}$ & $\begin{array}{c}\text { In vitro } \\
\text { Rooting (\%) }\end{array}$ & $\begin{array}{l}\text { Mean } n^{\circ} \text { of } \\
\text { roots/shoot }\end{array}$ & $\begin{array}{c}\text { Mean root } \\
\text { length }(\mathrm{mm})\end{array}$ & $\begin{array}{c}\text { Acclimatization in } \\
\text { greenhouse (\%) }\end{array}$ \\
\hline \multirow{2}{*}{ "Cacharela" } & 0.1 & 13 & $1.14 \pm 0.38 \mathrm{ab}$ & $33.00 \pm 6.63$ & 81.25 \\
\hline & 0 & 0 & $0.00 \pm 0.00 \mathrm{a}$ & $0.00 \pm 0.00$ & ----- \\
\hline \multirow{2}{*}{ “Camoesa” } & 0.1 & 91 & $5.67 \pm 2.46 \mathrm{f}$ & $33.59 \pm 8.06$ & 69.38 \\
\hline & 0 & 59 & $3.78 \pm 2.26 \mathrm{~d}$ & $38.31 \pm 11.29$ & 96.87 \\
\hline \multirow{2}{*}{ “Gravillán” } & 0.1 & 65 & $2.97 \pm 1.75 \mathrm{~cd}$ & $47.31 \pm 11.78$ & 57.14 \\
\hline & 0 & 11 & $2.00 \pm 1.26 \mathrm{ab}$ & $63.50 \pm 10.85$ & 83.33 \\
\hline \multirow{2}{*}{ "José Antonio" } & 0.1 & 59 & $3.53 \pm 2.42 \mathrm{~d}$ & $59.00 \pm 25.21$ & 81.25 \\
\hline & 0 & 39 & $2.76 \pm 2.23 b c$ & $82.43 \pm 34.61$ & 52.38 \\
\hline \multirow{2}{*}{ “Ollo Mouro" } & 0.1 & 0 & $0.00 \pm 0.00 \mathrm{a}$ & $0.00 \pm 0.00$ & ------ \\
\hline & 0 & 4 & $1.00 \pm 0.00 \mathrm{a}$ & $85.66 \pm 7.07$ & 50.00 \\
\hline "Príncipe & 0.1 & 4 & $1.00 \pm 0.00 \mathrm{a}$ & $61.50 \pm 13.43$ & 100.00 \\
\hline Grande" & 0 & 0 & $0.00 \pm 0.00 \mathrm{a}$ & $0.00 \pm 0.00$ & ------- \\
\hline \multirow{2}{*}{ "Repinaldo" } & 0.1 & 91 & $4.12 \pm 1.92 \mathrm{e}$ & $73.49 \pm 33.55$ & 87.75 \\
\hline & 0 & 80 & $3.39 \pm 1.56 \mathrm{~d}$ & $48.86 \pm 26.09$ & 76.74 \\
\hline "Tres en & 0.1 & 0 & $0.00 \pm 0.00 \mathrm{a}$ & $0.00 \pm 0.00$ & ------ \\
\hline Cunca” & 0 & 0 & $0.00 \pm 0.00 \mathrm{a}$ & $0.00 \pm 0.00$ & ------ \\
\hline \multirow{2}{*}{ "Barburiña"* } & 0.1 & 7 & $2.00 \pm 0.82 \mathrm{ab}$ & $90.25 \pm 27.71$ & 75.00 \\
\hline & 0 & 2 & $1.00 \pm 0.00 \mathrm{a}$ & $1.00 \pm 0.00$ & 0.00 \\
\hline "Manteca & 0.1 & 0 & $0.00 \pm 0.00 \mathrm{a}$ & $0.00 \pm 0.00$ & ------ \\
\hline Oscura"* & 0 & 0 & $1.00 \pm 0.00 \mathrm{a}$ & $57.33 \pm 6.80$ & 66.66 \\
\hline
\end{tabular}

The data are expressed as means \pm SD. The different letters indicate significant differences in the means between treaments (Tukey $\mathrm{P}=0.05$ ). The cultivars marked with *belong to pear trees. 


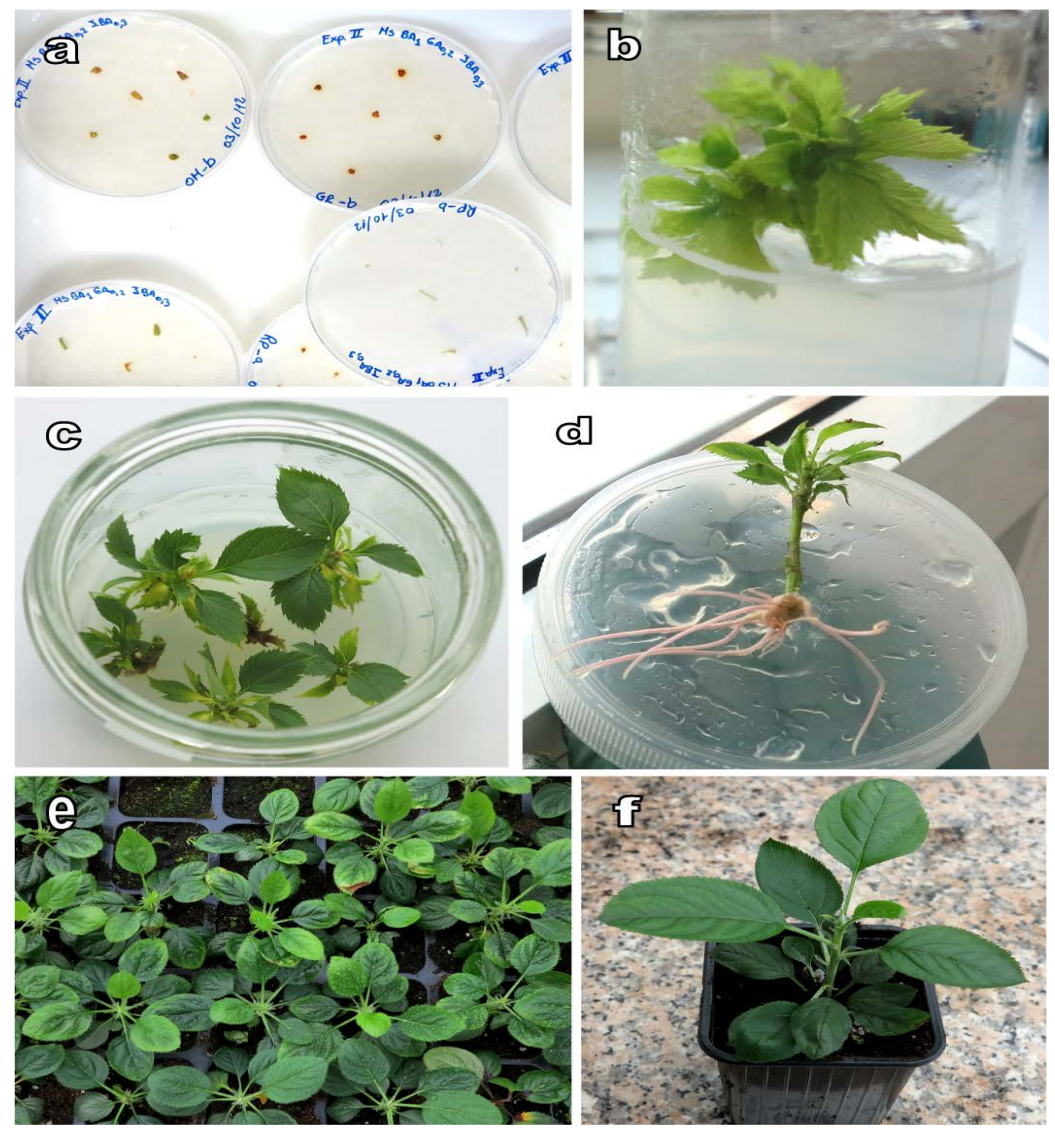

Figure 6. Complete procedure for micropropagation (a) apple shoot tips establishment in vitro (b) (c) multiplication stage (d) in vitro shoot rooting (e) Transplantation of apple plantlets after for 4 weeks in rooting medium in pots under rooting chamber conditions at a temperature of $24^{\circ} \mathrm{C} \pm 2^{\circ} \mathrm{C}$ and (f) acclimatization under greenhouse conditions after one month.

The presence of $\mathrm{GA}_{3}$ together with $\mathrm{BA}$ and IBA promotes growth of established buds [26]; however, some authors indicate that $\mathrm{GA}_{3}$ inhibits the development of apple shoots at the multiplication stage and even at the rooting stage [34]. In the present study with the eight apple and two pear cultivars, MS medium supplemented with BA $\left(1 \mathrm{mg} \cdot \mathrm{L}^{-1}\right) \mathrm{GA}_{3}\left(0.2 \mathrm{mg} \cdot \mathrm{L}^{-1}\right)$ and IBA $\left(0.3 \mathrm{mg} \cdot \mathrm{L}^{-1}\right)$ proved suitable for establishing all selected cultivars. However, $\mathrm{GA}_{3}$ was suppressed from multiplication stage media.

$\mathrm{BA}$ is one of the most commonly used and effective cytokinins for developing axillary buds in both apple and pear [35] [36]. Other cytokinins such as Zea, 2iP and kinetin [37] are less commonly used, and the use of phenylurea derivatives such as thidiazuron and N-2-chloro-4-pyridyl)- $\mathrm{N}$-phenylurea (CPPU) is sometimes described on shoot proliferation in pear cultures [38]. However, theeffectiveness of any of these cytokinins in the multiplication medium will depend primarily on the genotype of the cultivar [28].

Several authors have reported the use of shoot tips of a few millimeters for the establishment [39] [40] specially to eradicate viruses. In our study, for very small apical shoots $(<3 \mathrm{~mm})$ we placed a sterile filter paper disc in the upper part of 
the setting medium, avoiding, to a great extent, the rapid proliferation of endophytic bacteria in the establishment phase. This allowed the development of shoot tips by improving the survival rate of the in vitro starting material.

At the multiplication stage, the in vitro induction of axillary buds capable of forming shoots is widely used to propagate fruit trees. Furthermore, the risk of mutation in clones derived from axillary buds is much lower than the risk of mutation during organogenesis from callus.

Both BA and TDZ are the most frequently used cytokinins in apple regeneration and they have been compared in several studies [28]. TDZ has been found to be more effective than BA for shoot regeneration in numerous trials [25] [41] [42]. The optimal TDZ concentration largely depended on genotype. We found that growth media containing the highest level of TDZ $\left(1 \mathrm{mg} \cdot \mathrm{L}^{-1}\right)$ yielded the highest number of shoots in only four of the selected cultivars "José Antonio" and "Tres en Cunca" apple cultivars, as well as the pear cultivars "Barburiña" and "Manteca Oscura". For the other cultivars, the lowest concentrations of TDZ ( 0.25 and $\left.0.5 \mathrm{mg} \cdot \mathrm{L}^{-1}\right)$ were more suitable and favorable. However, at higher concentration of TDZ, callus formation was observed and smaller shoots developed. Although some authors have reported otherwise [43], we found that the concentration of TDZ affected shoot length in all cultivars, with visibly shorter shoots produced at the highest concentration of $1 \mathrm{mg} \cdot \mathrm{L}^{-1}$. Even though the regenerated shoots did not hyperhydric in many apple and pear cultivars, visible differences were observed in the morphology of regenerated shoots: more compact shoots with short internodes and small rolled leaves with wavy edges.

Results from studies with Pyrus pyrifolia showed that the presence of hyperhydricity in the explants was influenced by the type of cytokinin. In our study, more hyperhydric buds appeared when TDZ instead than BA or cytokinins derived from adenine were used, and the concentration had little influence [44], TDZ had a stronger effect on hyperhydricity, as also observed in Malus pumila [42]. The results of the present study showed that high concentrations of TDZ or BA were more important in relation to the formation of hyperhydric shoots than whether the cytokinin was derived from phenylurea or adenine. However, high concentrations ( $\left.1 \mathrm{mg} \cdot \mathrm{L}^{-1}\right)$ of other cytokinins tested ( $2 \mathrm{iP}$ and zea) did not produce hyperhydricity, except in apple trees cultivar "Camoesa", "Gravillán" and "Ollo Mouro" with an average between 0.02 and 0.96 hyperhydric shoots. This confirms that the type of cytokinin and optimal concentration for micropropagation of woody plants may depend on genotype [38].The medium of multiplication selected by the rate and quality of the buds that grew in them have been three: MS BA $0.25 \mathrm{mg} \cdot \mathrm{L}^{-1} \mathrm{IBA} 0.1 \mathrm{mg} \cdot \mathrm{L}^{-1}$ for cultivars "Cacharela", "Camoesa", "Gravillán" and "Ollo Mouro"; MS BA $0.5 \mathrm{mg} \cdot \mathrm{L}^{-1} \mathrm{IBA} 0.1 \mathrm{mg} \cdot \mathrm{L}^{-1}$ for "José Antonio", "Príncipe Grande", "Repinaldo" and "Tres en Cunca" and MS BA $1 \mathrm{mg} \cdot \mathrm{L}^{-1}$ for two pears "Barburiña" and "Manteca Oscura".

Most studies involving in vitro rooting of apple and pear use auxins, such as IBA and IAA. The use of IBA has been shown to play an important role in the rooting of these fruit trees as well as in different plants; however, the optimum 
concentration of IBA for maximum rooting differs between species and cultivars [45] [46]. We observed that the presence of IBA in the medium significantly increased the in vitro rooting of the shoots in all cultivars, with the exception of "Ollo Mouro" and "Manteca Oscura", compared to auxin-free medium. Rooting rates were achieved in most of the studied cultivars on medium supplemented with IBA $\left(0.1 \mathrm{mg} \cdot \mathrm{L}^{-1}\right)$. Regenerated plantlets were successfully transferred to the greenhouse for acclimatization. However, production of a limited number of plantlets has been achieved in some cultivars due to the low rate of in vitro rooting in MS0 medium. In addition, genotype strongly influenced the process of acclimatization to ex-vitro conditions, which is another factor limiting the success of micropropagation of these fruit trees cultivars.

The most responsive cytokinins for inducing axillary buds from apple and pear shoots were TDZ and BA, while Zea and $2 \mathrm{iP}$ were much less effective. TDZ was more effective than BA for producing buds in all apple and pear cultivars tested. In both pear cultivars and the apple cultivars "Jose Antonio" and "Tres en Cunca" better responses were obtained at the highest concentration $\left(1 \mathrm{mg} \cdot \mathrm{L}^{-1}\right)$ of TDZ, while the other apple cultivars showed a better response with lower concentrations ( 0.25 and $0.5 \mathrm{mg} \cdot \mathrm{L}^{-1}$ ) of TDZ. BA was the most effective cytokinin (at a concentration of $1 \mathrm{mg} \cdot \mathrm{L}^{-1}$ ) for most of the apple cultivars tested ("Cacharela", "Camoesa", "osé Antonio", "Ollo Mouro", "Principe Grande", "Repinaldo" and "Tres en Cunca") and for both pear cultivars, while in the apple cultivar "Gravillán" a better response was obtained with a lower concentration $\left(0.5 \mathrm{mg} \cdot \mathrm{L}^{-1}\right)$ of BA.

\section{Conclusion}

To conclude, BA and TDZ proved to be the most effective cytokinins for multiplication of all apple and pear cultivars tested, varying the optimal concentration according to the genotype. But the use of TDZ was ruled out because of malformations in leaves and stems in all cultivars, although with the three concentrations of TDZ higher rates of multiplication were obtained. The presence of IBA $0.1 \mathrm{mg} \cdot \mathrm{L}^{-1}$ in the rooting medium was effective only on five apple cultivars, but did not have a positive response (less than 10\%) on root formation in the remaining apple and pear tree cultivars selected.

\section{Acknowledgements}

The authors are grateful to the CIAM germplasm bank of the Mabegondo Agricultural Research Center (INGACAL) for the agreement signed for the transfer of plant material from Malus and Pyrus to our laboratory at the University of Santiago de Compostela.

\section{References}

[1] FAO (2013) Fuente. http://faostat3.fao.org

[2] Flachowsky, H. and Höfer, M. (2010) The German Fruit Genebank, a Decentral Network for Sustainable Preservation of Fruit Genetic Resources. Journal für Kul- 
turpflanzen, 62, 9-16.

[3] Pereira-Lorenzo, S., Ramos-Cabrer, A.M., Ascasíbar-Errasti, J. and Piñeiro-Andión, J. (2003) Analysis of Apple Germplasm in Northwestern Spain. Journal of the American Society for Horticultural Science, 128, 67-84.

[4] Pereira-Lorenzo, S., Ramos-Cabrer, A.M. and Díaz-Hernández, M.B. (2007) Evaluation of Genetic Identity and Variation of Local Apple Cultivars (Malus $x$ domestica Borkh.) from Spain Using Microsatellite Markers. Genetic Resources Crop Evolution, 54, 405-420. https://doi.org/10.1007/s10722-006-0003-7

[5] European Plant Protection Organization (1999) EPPO Standars PM 4/27(1) Certification Schemes Malus, Pyrusand cydonia. European Plant Organization, Paris.

[6] Panattoni, A., Luvisi, A. and Triolo, E. (2013) Review. Elimination of Viruses in Plants: Twenty Years of Progress. Spanish Journal of Agriculture Research, 11, 173 188. https://doi.org/10.5424/sjar/2013111-3201

[7] Manganaris, G.A., Economou, A.S., Boubourakas, I.N. and Katis, N.I. (2003) Elimination of PPV and PNRSV through Thermotherapy and Meristem-Tip Culture in Nectarine. Plant Cell Reports, 22, 195-200.

https://doi.org/10.1007/s00299-003-0681-y

[8] Paprstein, F., Sèdlak, J., Polak, J., Svobodova, L., Hassan, M. and Bryxiova, M. (2008) Results of in vitro Thermotherapy of Apple Cultivars. Plant Cell Tissue and Organ Culture, 94, 347-352. https://doi.org/10.1007/s11240-008-9342-8

[9] Deberegh, P.C. and Zimmerman, R.H. (2002) Micropropagation Technology and Application. Kluwer Academic Publishers, Boston.

[10] Sèdlak, J. and Paprstein, F. (2016) In Vitro Establishment and Proliferation of Apple Cultivars. Acta Horticulturae (ISHS), 1113, 107-112. https://doi.org/10.17660/ActaHortic.2016.1113.15

[11] Xu, J., Wang, Y., Zhang, Y. and Chai, T.Y. (2008) Rapid in Vitro Multiplication and ex Vitro Rooting of Malus zumi (Matsumura) Rehd. Acta Physiologiae Plantarum, 30, 129-132. https://doi.org/10.1007/s11738-007-0075-9

[12] Muniz, A.W., Luiz de Sá, E., Dalagnol, G.L. and Filho, J.A. (2013) Rooting and Acclimatization of Micropropagated Marubakai Do Apple Rootstock Using Adesmialatifolia rhizobia. SpringerPlus, 2, 437. https://doi.org/10.1186/2193-1801-2-437

[13] Dobránszki, J. and Teixeira da Silva, J.A. (2010) Micropropagation of Apple-A Review. Biotechnology Advances, 28, 462-488. https://doi.org/10.1016/j.biotechadv.2010.02.008

[14] Hirabayashi, T., Moriguchi, T., Kozaki, I., Yamamoto, Y. and Matsuzaki, S. (1987) In Vitro Propagation of Pyrus Shoots Tips. International Society for Horticultural Science VII International Symposium on Pear, 14, 9-16.

[15] Banno, K., Yoshida, K., Hayashi, S. and Tanabe, K. (1989) In Vitro Propagation of Japanese Pear Cultivars. Journal Japanese Society Horticultural Science, 58, 37-42. https://doi.org/10.2503/jjshs.58.37

[16] Erig, A.C. and Fortes, G.R. (2002) In Vitro Establishment of Pear (Pyrus spp.) Starting from Meristems and Buds. Ciencia Rural, 32, 577-582. https://doi.org/10.1590/S0103-84782002000400005

[17] Thakur, A. and Kanwar, J.S. (2008) Mircropropagation of "Wild Pear" Pyrus pyrifolia (Burm F) Nakai I Explant Establishment and Shoot Multiplication. Notulae Botanicae Horti Agrobotanici Cluj-Napoca, 36, 103-108.

[18] Lane, W.D., Iketani, H. and Hayashi, T. (1998) Shoot Regeneration from Cultured Leaves of Japanese Pear (Pyrus pyrifolia). Plant Cell Tissue and Organ Culture, 54, 
9-14. https://doi.org/10.1023/A:1006032707849

[19] Caboni, E., D’Angeli, S., Chiappetta, A., Innocenti, A.M., Van Onckelen, H. and Damiano, C. (2002) Adventitious Shoot Regeneration from Vegetative Shoot Apices in Pear and Putative Role of Cytokinin Accumulation in the Morphogenetic Process. Plant Cell Tissue and Organ Culture, 70, 199-206. https://doi.org/10.1023/A:1016304106529

[20] Poudyal, B.K., Zhang, Y. and Du, G. (2008) Adventitious Shoot Regeneration from the Leaves of Some Pear Varieties (Pyrus spp.) Grown in Vitro. Frontiers of Agriculture in China, 2, 82-92. https://doi.org/10.1007/s11703-008-0016-4

[21] Yepes, L.M. and Aldwinckle, S.H. (1994) Micropropagation of Thirteen Malus Cultivars and Rootstocks, and Effect of Antibiotics on Proliferation. Plant Grow Regulation, 15, 55-67. https://doi.org/10.1007/BF00024677

[22] Tang, H., Luo, Y. and Liu, C. (2008) Plant Regeneration from in Vitro Leaves of Four Commercial Pyrus Species. Plant, Soil and Environment, 54, 140-148.

[23] George, E.F. and Davies, W. (2008) Effects of the Physical Environment. In: George, E.F., Hall, M.A. and De Klerk, G.J., Eds., Plant Propagation by Tissue Culture, 3rd Edition, Netherlands Springer, Dordrecht, 423-464.

[24] Berardi, G., Infante, R. and Neri, D. (1993) Micropropagation of Pyrus calleryana DCN from Seedlings. Scientia Horticulturae, 53, 157-165.

https://doi.org/10.1016/0304-4238(93)90146-H

[25] Sarwar, M. and Skirvin, R.M. (1997) Effect of Thidiazuron and 6-Benzylaminopurine on Adventitious Shoot Regeneration from Leaves of Three Strains of 'Mcintosh’ Apple (Malus $x$ domestica Borkh.) in Vitro. Scientia Horticulturae, 68, 95-10. https://doi.org/10.1016/S0304-4238(96)00971-5

[26] Shibli, R.A., Ajlouni, M.M., Jaradat, A., Aljanabi, S. and Shatnawi, M. (1997) Micropropagation in Wild Pear (Pyrus syrica). Scientia Horticulturae, 68, 237-242. https://doi.org/10.1016/S0304-4238(96)00972-7

[27] Dobránszki, J., Hudák, I., Magyar-Tábori, K., Jámbor-Benczúr, E., Galli, Z.S. and Kiss, E. (2004) Effects of Different Cytokinins on the Shoot Regeneration from Apple Leaves of 'Royal Gala' and 'M.26'. Horticultural Science, 10, 69-75.

[28] Magyar-Tábori, K., Dobránszki, J., Teixeira da Silva, A., Bulley, S.M. and Hudák, I. (2010) The Role of Cytokinins in Shoot Organogenesis in Apple. Plant Cell Tissue and Organ Culture, 101, 251-267. https://doi.org/10.1007/s11240-010-9696-6

[29] Kalinina, A. and Brown, D.C.W. (2007) Micropropagation of Ornamental Prunus spp. and GF305 Peach, a Prunus Viral Indicator. Plant Cell Reports, 26, 927-935. https://doi.org/10.1007/s00299-007-0315-X

[30] Murashige, T. and Skoog, F. (1962) A Revised Medium for Rapid Growth and Bioassay with Tobacco Tissues Cultures. Physiologiae Plantarum, 15, 473-497. https://doi.org/10.1111/j.1399-3054.1962.tb08052.x

[31] Li, X., Xu, M. and Korban, S.S. (2002) DNA Methylation Profiles Differ between Field and in Vitro-Grown Leaves of Apple. Journal of Plant Physiology, 159, 12291234. https://doi.org/10.1078/0176-1617-00899

[32] International Business Machines Corporation (2011) IBM SPSS Statistics for Windows, Version 20.0. IBM Corp., Armonk.

[33] Chakrabarty, D., Hahn, E.J., Yoon, Y.J. and Paek, K.Y. (2003) Micropropagation of Apple Rootstock M.9 EMLA Using Bioreactor. Journal of Horticultural Science and Biotechnology, 78, 605-609. https://doi.org/10.1080/14620316.2003.11511671

[34] Rodriguez, R., Diaz-Sala, C., Cuozzo, L. and Ancora, G. (1991) Pear in Vitro Prop- 
agation Using a Double-Phase Culture System. HortScience, 26, 62-64.

[35] Wang, L.P., Wang, G.P., Hong, N., Tang, R.R. and Deng, X.Y. (2006) Effect of Thermotherapy on Elimination of Apple Stem Grooving Virus and Apple Chlorotic Leaf Spot Virus for in Vitro Cultured Pear Shoot Tips. HortScience, 41, 729-732.

[36] Dalal, M.A., Das, B., Sharma, A.K., Mir, M.A. and Sounduri, A.S. (2006) In Vitro Cloning of Apple (Malus domestica Borkh) Employing Forced Shoot Tip Cultures of M9 Rootstock. Indian Journal of Biotechnology, 5, 543-550.

[37] Moretti, C., Scozzoli, A., Pasini, D. and Paganelli, F. (1992) In Vitro Propagation of Pear Cultivars. Acta Horticulturae, 300, 115-118. https://doi.org/10.17660/ActaHortic.1992.300.12

[38] Kadota, M. and Niimi, Y. (2003) Effects of Cytokinin Types and Their Concentrations on Shoot Proliferation and Hyperhydricity in in Vitro Pear Cultivar Shoots. Plant Cell Tissue and Organ Culture, 72, 261-265. https://doi.org/10.1023/A:1022378511659

[39] Wang, M.R., Li, B.Q., Feng, C.H. and Wang, Q.C. (2016) Culture of Shoot Tips from Adventitious Shoots Can Eradicate Apple Stem Pitting Virus but Fails in Apple Stem Grooving Virus. Plant Cell Tissue and Organ Culture, 125, 283-291. https://doi.org/10.1007/s11240-016-0948-y

[40] Tan, R.R., Wang, L.P., Hong, N. and Wang, G.P. (2010) Enhanced Efficiency of Virus Eradication Following Thermotherapy of Shoot-Tip Cultures of Pear. Plant Cell Tissue and Organ Culture, 101, 229-235. https://doi.org/10.1007/s11240-010-9681-0

[41] Fasolo, F., Zimmerman, R.H. and Fordham, I. (1989) Adventitious Shoots Formation on Excised Leaves of in Vitro Grown Shoots of Apple Cultivars. Plant Cell Tissue and Organ Culture, 16, 75-87. https://doi.org/10.1007/BF00036516

[42] Pawlicki, N. and Welander, M. (1994) Adventitious Shoot Regeneration from Leaf Segments of in Vitro Cultured Shoots of the Apple Rootstock Jork 9. Horticultural Science, 69, 687-696. https://doi.org/10.1080/14620316.1994.11516501

[43] Hanke, V., Rohde, A. and Grafe, C. (1991) Studies on Regeneration from Somatic Tissue in Vitro. Adventitious Shoot Formation on Leaf Explants in Apple (Malus $X$ domestica Borkh). Dresden-Pillnitz, 56, 214-220.

[44] Huetteman, C.A. and Preece, J.E. (1993) Thidiazuron: A Potent Cytokinin for Woody Plant Tissue Culture. Plant Cell Tissue and Organ Culture, 33, 105-119. https://doi.org/10.1007/BF01983223

[45] Xiao, Z., Ji, N., Zhang, X., Zhang, Y., Wang, Y., Wu, T., Xu, X. and Han, Z. (2014) The Loss of Juvenility Elicits Adventitious Rooting Recalcitrance in Apple Rootstocks. Plant Cell Tissue and Organ Culture, 119, 51-63. https://doi.org/10.1007/s11240-014-0513-5

[46] Damiano, C., Frattarelli, A. and Giorgioni, M. (2000) Micropropagation of Temperate Fruit Trees through Temporary Immersion Technique: The Case of Pear. Bulletin of the Fruit Tree Research Station. Series A, 120-121. 


\section{Abbreviations}

BA: 6-Benzylaminopurine

cv: Cultivar

GA3: Gibberellic Acid

IBA: Indol-3-Butyric Acid

MS: Murashige and Skoog Medium

PGRs: Plant Growth Regulators

TDZ: Thidiazuron (1-Phenyl-3-(1,2,3,-Thiadiazol-5-yl) Urea

Zea: Zeatin

2-iP: N6-(2-Isopentyl) Adenine

Submit or recommend next manuscript to SCIRP and we will provide best service for you:

Accepting pre-submission inquiries through Email, Facebook, LinkedIn, Twitter, etc. A wide selection of journals (inclusive of 9 subjects, more than 200 journals)

Providing 24-hour high-quality service

User-friendly online submission system

Fair and swift peer-review system

Efficient typesetting and proofreading procedure

Display of the result of downloads and visits, as well as the number of cited articles Maximum dissemination of your research work

Submit your manuscript at: http://papersubmission.scirp.org/

Or contact ajps@scirp.org 